\title{
Role of Microbiota and Tryptophan Metabolites in the Remote Effect of Intestinal Inflammation on Brain and Depression
}

\author{
Barbora Waclawiková and Sahar El Aidy * (10 \\ Department of Molecular Immunology and Microbiology, Groningen Biomolecular Sciences and Biotechnology \\ Institute (GBB), University of Groningen, Nijenborgh 7, 9747 AG Groningen, The Netherlands; \\ b.waclawikova@rug.nl \\ * Correspondence: sahar.elaidy@rug.nl; Tel.: +31-(0)50-363-2201
}

Received: 26 May 2018; Accepted: 22 June 2018; Published: 25 June 2018

\begin{abstract}
The human gastrointestinal tract is inhabited by trillions of commensal bacteria collectively known as the gut microbiota. Our recognition of the significance of the complex interaction between the microbiota, and its host has grown dramatically over the past years. A balanced microbial community is a key regulator of the immune response, and metabolism of dietary components, which in turn, modulates several brain processes impacting mood and behavior. Consequently, it is likely that disruptions within the composition of the microbiota would remotely affect the mental state of the host. Here, we discuss how intestinal bacteria and their metabolites can orchestrate gut-associated neuroimmune mechanisms that influence mood and behavior leading to depression. In particular, we focus on microbiota-triggered gut inflammation and its implications in shifting the tryptophan metabolism towards kynurenine biosynthesis while disrupting the serotonergic signaling. We further investigate the gaps to be bridged in this exciting field of research in order to clarify our understanding of the multifaceted crosstalk in the microbiota-gut-brain interphase, bringing about novel, microbiota-targeted therapeutics for mental illnesses.
\end{abstract}

Keywords: microbiota; kynurenine pathway; serotonin; inflammation; gut motility

\section{Introduction}

The complex communities of the microbiota that inhabit the mammalian gut have a significant impact on the health of their host. These gut bacteria has coevolved with the human body to perform numerous beneficial functions ranging from being simple fermenters of food to having profound effects on the host immune development, metabolism and food preferences, brain development, stress responses, pain, and behavior [1-5]. Consequently, disruptions or alterations in this resilient relationship are a significant factor in many diseases such as inflammatory gastrointestinal diseases and neuropsychiatric disorders, including depression [1,6-8].

Depression is a severe neuropsychiatric disease with multiple comorbidities in play. According to the World Health Organization (WHO), this longstanding mental disorder affects more than 300 million people of all ages worldwide [9]. Moreover, it is the leading cause of disability in modern society, and approximately one million people suffering from depression commit suicide every year [9]. It is widely recognized now that depression is closely linked with inflammation, and disrupted serotonergic systems throughout the human body, including the gut [10-16]. In fact, in a state of inflammation, not only high levels of proinflammatory cytokines are produced but also altered levels of neurotransmitters, such as serotonin, a derivative of tryptophan metabolism, are detected in the gut [17-19]. The presence of vast majority of bodily serotonin and immune cells in the gut in close 
proximity to the trillion of the gut-associated microbes implies the gut microbiota is likely to be an orchestrator in this multifaceted crosstalk between inflammation, serotonin, and depression, as will be discussed in this review article.

\section{Gastrointestinal Inflammation and Depression}

In a state of intestinal inflammation, the immune system responds by producing various proinflammatory cytokines and metabolites, several of which are detected in the systemic blood circulation [20]. The fact that these molecules can cross the blood-brain barrier suggests that they can signal to the brain to ultimately result in serious changes in behavior [21]. Several routes, by which cytokines and metabolites present in the gut can influence the brain and behavior, have been described; (1) neural, (2) humoral, (3) cellular, and (4) carrier route [22] (Figure 1A). In the neural route, afferent nerves, such as the vagus nerve, are involved. Vagal nerves are activated by proinflammatory cytokines and other metabolites released by immune cells, neurons or intestinal bacteria during intestinal inflammation or infections [23] (Figure 1 $\mathrm{A}_{\mathrm{a}}$ ). This cascade leads to activation of the hypothalamus-pituitary-adrenal axis, thus increased levels of cortisol (stress hormone) and decreased levels of brain-derived neurotrophic factor [21]. The humoral route involves signaling via the circumventricular organs (CVOs), which have been described as a way by which leukocytes can reach the central nervous system [24]. CVOs are areas in the brain that lack an intact blood-brain barrier, thus allow molecules with limited access to the brain to migrate [25] (Figure $1 \mathrm{~A}_{\mathrm{b}}$ ). The carrier route includes cytokine transporters at the blood-brain barrier, where circulating cytokines can access the brain via the energy- and carrier-dependent active transport system or via no energy-dependent carrier-mediated facilitated diffusion system, commonly called saturable transport systems [26] (Figure $1 A_{c}$ ). Finally, the cellular route involves cytokine receptors, such as receptors for tumor necrosis factor $\alpha$ (TNF- $\alpha$ ) and interleukin (IL)-1 $\beta$, expressed on non-neuronal cells in the brain, such as microglia and astrocytes [27-29]. Binding of TNF- $\alpha$ and IL-1 $\beta$ to their receptors in the brain activates cerebral NF- $\kappa B$ signaling pathway and induces the production of secondary cytokines, which can promote a depressed mood $[29,30]$ (Figure $1 A_{d}$ ). Indeed, proinflammatory cytokines, such as interferon- $\gamma$ (IFN- $\gamma$ ), IL-2, TNF- $\alpha$, and inflammatory markers such as $C$ reactive protein (CRP), have been linked to higher risk of depression [31,32]. All together, these pathways show a number of sophisticated signaling mechanisms in the brain, which when stimulated by molecules produced during intestinal inflammation could lead to altered brain functionality, potentially leading to progression of depression.

\subsection{A Gut Perspective on the Role of Tryptophan Metabolites in Depression}

Tryptophan is an essential amino acid, derived from the diet [33]. Apart from its role in protein synthesis, tryptophan and its metabolites are associated with numerous physiological functions, such as immune homeostasis, but also with inflammatory response [34]. Once absorbed in the gut, tryptophan can cross the blood-brain barrier to participate in serotonin synthesis [35]. However, there are many other pathways through which tryptophan can be readily metabolized in the gut, thereby influencing its availability to pass the blood-brain barrier. Among these pathways are the kynurenine [36] and the serotonin synthesis pathways within the gut [37,38]. Kynurenine and serotonin are vital signaling molecules in immune response and gut-brain communication [34,39,40]. Most of the digested tryptophan (about 90\%) is metabolized along the kynurenine biosynthesis pathways [41], while only approximately $3 \%$ is metabolized into serotonin throughout the body, and the rest is degraded by the gut microbiota to produce indole and its derivatives [42]. This implies a strong competition between serotonin and the first downstream metabolites from the kynurenine pathway, kynurenine, for the available tryptophan, as described below. In inflammatory conditions, more kynurenine is produced on the expenses of serotonin [43,44], which, if happens also in the brain, results in behavioral changes including persistent sadness, loss of interest, and decreased energy levels [45] (Figure 1A). 


\subsection{Gut Inflammation-Induced Kynurenine Biosynthesis; Possible Cause of Altered Kynurenine Pathway in the} Brain during Depression?

Tryptophan forms kynurenine via the rate-limiting enzyme, indoleamine-2,3-dioxygenase (IDO) enzyme, found ubiquitously in all tissues, including the gut, and tryptophan-2,3-dioxygenase (TDO), which is localized in the liver [41]. The activity of TDO and IDO is uniquely induced by different stimuli; while TDO is induced by stress-elevated glucocorticoids, such as cortisol [46], IDO is induced during intestinal inflammation [47] by proinflammatory stimuli, with interferon $\gamma$ (IFN- $\gamma$ ) being the most potent inducer [48]. Induction of IDO results in a shift in the tryptophan metabolism towards the production of kynurenine and its downstream metabolites; kynurenic acid, anthranilic acid, and quinolinic acid rather than serotonin synthesis [47,49] (Figure 1A,B). Moreover, activated IDO accelerates the degradation of serotonin into formyl-5-hydroxykynuramine [50,51]. Degradation of serotonin yields reactive oxygen species byproducts and subsequently inflammation [52]. This further intensifies serotonin deficiency, leading to the disruption in neurotransmission and consequently causes depression.

In contrast to kynurenic acid and quinolinic acid, kynurenine and anthranilic acid can cross the blood-brain barrier via the saturable transfer [53]. This suggests that inflammatory-induced altered levels of kynurenine in the gut may transfer to the blood circulation and ultimately to the brain, resulting in altered levels of kynurenine and its metabolites, kynurenic acid, and quinolinic acid (Figure 1A). In fact, during inflammation, the enzymes of the kynurenine pathway are activated leading to changed production of kynurenic and quinolinic acids. Depression is believed to arise from the excessive production of the neurotoxic quinolinic acid together with a reduction in kynurenic acid [54]. Reduced levels of kynurenic acid have been correlated with severe depressive and suicidal symptoms [55,56], and decreased blood levels of this molecule has been detected in the patients with major depressive disorder [57]. Quinolinic acid is a neurotoxic agent, and its production is significantly enhanced by proinflammatory cytokines through their stimulation of the rate limiting step enzyme in the quinolinic acid pathway, kynurenine-3-monooxygenase (KMO) enzyme [58,59]. For instance, levels of quinolinic acid in the cerebrospinal fluids of suicide attempters showed around $300 \%$ increase compared to healthy controls [60]. In the brain, quinolinic acid acts as an agonist of $N$-methyl-D-aspartate (NMDA) receptors, which play a key role in the regulation of synaptic function [61]. Activation of NMDA receptors upon binding to quinolinic acid has been described to be another mechanism involved in promotion of depression [49]. Specifically, when microglia are stimulated by proinflammatory cytokines, glutamate, another agonist of NMDA receptors, and the main excitatory neurotransmitter in the central nervous system, is released leading to additional activation of NMDA receptors [61]. Therefore, quinolinic acid alone or in combination with glutamate, can enhance NMDA receptor activation and subsequently lead to depression [49]. Intriguingly, a high proportion of the enteric neurons in the gut express the NMDA-type glutamate receptors [62,63]. In line with these observations, previous data have suggested that enhanced activation of NMDA receptors maybe involved in altered inflammation-linked motility and in inflammatory-induced nociception $[64,65]$ as a remote consequence of intestinal inflammation on the brain [66] (Figure 1B). In contrast to quinolinic acid, kynurenic acid is an indigenous antagonist of the enteric NMDA receptors, thereby suppressing the hypermobility of the gut associated with the activated NMDA receptors and excitability of the enteric neurons during an intestinal inflammatory response. Collectively, the current data support an effect of intestinal inflammation on redirecting the tryptophan metabolic pathway towards kynurenine rather that serotonin biosynthesis. Kynurenine metabolites have a profound effect on the enteric nervous system and intestinal motility alteration. Whether altered gut motility can stimulate a state of depression and whether changes in intestinal kynurenine metabolism could be the source of altered levels of these metabolites in the brain, warrant more investigation. 


\subsection{Intestinal Inflammation and Disrupted Serotonin Signaling System: From Alterated Gut Functionality to Development of Depression}

Serotonin is a key-signaling regulator that modulates a wide range of effects on host physiology, including the control of gut motility, secretory reflexes, platelet aggregation, regulation of immune responses, and regulation of mood and behavior [67]. Once tryptophan is absorbed in the gut, it crosses the blood-brain barrier to be partially metabolized into serotonin in the raphe nuclei within the brain stem [34]. However, the majority ( $95 \%)$ of serotonin in the body is synthesized, stored, and released in the gut, mainly from a subset of enteroendocrine cells called enterochromaffin cells in the intestinal mucosa [19]. The small amount of serotonin that is not in enterochromaffin cells is in the enteric nervous system, in particular, the myenteric plexus, which contains descending serotonergic interneurons [68] (Figure 1B).

Enterochromaffin cells, also known as epithelial sensory transducers, secrete serotonin in response to mucosal stimuli, such as microbiota metabolites as discussed below. Once synthesized, serotonin is secreted in the lamina propria, where it has access to the nerve fibers. This implies a large amount of serotonin is secreted in the extracellular space. Thus, to avoid receptors' desensitization by their contact with excessive amounts of serotonin, which is toxic [69], serotonin overflow must be efficiently controlled. One important player in serotonin uptake by gut epithelial cells, thus serotonergic termination, is the $\mathrm{Na}^{+} / \mathrm{Cl}^{-}$dependent, serotonin transporter (SERT). SERT, is a recently crystallized protein [70] comprised of 12 transmembrane domains, and is a member of a large superfamily of sodium/chloride dependent transporters, which also contain transporters for other neurotransmitters, such as dopamine and norepinephrine [71].

Secreted serotonin mediates its actions via several receptor subtypes [72], where it has been observed to affect epithelial cells' proliferation and secretion [73], but mainly acts as a regulator of the gut motility. Secretion of serotonin by enterochromaffin cells activates intrinsic primary afferent neurons (IPANs) in the submucosal plexus via its action on $5-\mathrm{HT}_{1 \mathrm{P}}$ receptor. These cells initiate peristaltic and secretory reflexes, which influences gut motility (Figure 1C). Moreover, intestinal serotonin activates extrinsic sensory nerves via its action on $5-\mathrm{HT}_{3}$, which are postsynaptic receptors found on the terminals of extrinsic sensory neurons terminal in the gut and transmit noxious signals to the brain [74] (Figure 1B). Though it does not initiate peristaltic movement, 5- $\mathrm{HT}_{3}$ conveys any kind of change in gut motility to the brain via its presence on myenteric IPANs and in the myenteric plexus, where they mediate fast excitatory neurotransmission [75]. Similarly, 5- $\mathrm{HT}_{4}$ receptors themselves do not initiate peristaltic reflexes, but because of their location at the terminals of submucosal IPANs, at synapses within the myenteric plexus, and at the neuromuscular junction, stimulation of 5- $\mathrm{HT}_{4}$ receptors is critical for these reflexes [76]. 5- $\mathrm{HT}_{4}$ receptors work through stimulating the production of the neurotransmitters acetylcholine and calcitonin gene-related peptide, which enhances the spread of stimuli around and through the gut wall, to ultimately enhance and maintain a normal gut motility $[77,78]$.

The strong link between inflammation, and disruptions of serotonin metabolism has been well established. Immune cells including lymphocytes, mast cells, dendritic cells and monocytes have all been reported to express SERT, serotonin receptors and enzymes involved in the production and metabolism of serotonin [79,80] (Figure 1C). T lymphocytes express the main components of serotonin metabolism, i.e., tryptophan hydroxylase (TPH), the first rate limiting enzyme involved in serotonin production, SERT, monoamine oxidase (MAO) [80], which breaks down serotonin into its metabolite 5-HIAA, and 5-HT receptors [80]. While resting, naïve T cells express very little TPH1, the TPH isoform present in the intestinal enterochromaffin cells, where intestinal serotonin is synthesized, activated T cells show approximately 30-fold higher expression of TPH1, suggesting increased levels of serotonin in activated $\mathrm{T}$ cells [81], and 5-HT receptors, including $5-\mathrm{HT}_{1 \mathrm{~B}}, 5-\mathrm{HT}_{2 \mathrm{~A}}, \mathrm{and}^{5-\mathrm{HT}_{7}}$ receptors [81]. However, expression of SERT in T cells is still questionable; León-Ponte et al. shows that neither naïve nor activated T cells express high-affinity SERT [81], however another study claims that SERT is present in T cells membranes [82] (Figure 1C). Thus, these contradictory conclusions warrant further investigation. B lymphocytes are also known to express 5-HT receptors, including 
5- $\mathrm{HT}_{1 \mathrm{~A}}, 5-\mathrm{HT}_{2 \mathrm{~A}}, 5-\mathrm{HT}_{3 \mathrm{~A}}$ and 5- $\mathrm{HT}_{7}$ [80], and activated B cells exhibit a significant increase in SERT expression [83] (Figure 1C). Whether B cells express other components of serotonin machinery and thus influencing serotonin signaling, it is still unknown. Like T cells, monocytes, the immature leukocytes that eventually differentiate into macrophages or dendritic cells, express the complete set of components needed for serotonin production [80]. Dendritic cells, have also been found to mediate the release of proinflammatory cytokines, IL-1 $\beta$ and IL-8 via $5-\mathrm{HT}_{3}, 5-\mathrm{HT}_{4}$, and $5-\mathrm{HT}_{7}$ receptor subtypes [84]. In fact, serotonin has been demonstrated as an important regulator of the immune system. For example, serotonin has been described to modulate proinflammatory cytokines production in human monocytes via stimulation of different 5-HT receptor subtypes, particularly $5-\mathrm{HT}_{3}, 5-\mathrm{HT}_{4}$, and $5-\mathrm{HT}_{7}$ receptors [85] (Figure 1C). Interestingly, deletion of 5- $\mathrm{HT}_{4}$ receptors in mice results in inflammatory response, slowed colonic motility, and behavioral abnormalities $[86,87]$. Similarly, reduced expression of SERT and subsequent altered serotonin levels, have been associated with different inflammatory and diarrheal disorders $[15,16,88]$. Targeted deletion of the SERT in mice led to increased colonic motility and increased water in stools [89] in a similar manner to that observed in inflammatory bowel disorders, where SERT expression is also reduced $[18,90]$. That the altered structure or expression of SERT leads to disrupted serotonin transmission [91], the current data point to a strong link between intestinal inflammation, disruption of serotonin signaling and the consequent alteration in gut motility, and development of depression. Whether the altered gut motility $[14,16,88,89,92,93]$ is the driving factor in inducting depression in this cascade is unclear. One plausible mechanism is via the gut motility-mediated changes in the microbial population complexity, which might exert detrimental effects on enteric and central neurons leading to a state of depression.

\section{Microbiota as an Orchestrator in the Crosstalk between Inflammation and Serotonin Imbalances}

The presence of vast number of gut microbiota in close proximity to serotonin and immune cells in the gut, makes it plausible to consider these bacteria as a conductor in the orchestra of intestinal inflammation and serotonin, to remotely result in a state of altered mood and depression in the brain (Figure 1).

\subsection{Gut Microbiota and Intestinal Immune (Hyper)-Stimulation}

It is well-established that the gut microbiota plays a critical role in both innate and adaptive immunity, where it mediates the formation, maturation, and function of several immune cells [94]. Interactions between the gut bacteria and gut mucosa regulate the production of numerous proinflammatory cytokines [95-97]. Several species within the gut bacteria have been shown to be essential in the development and maturation of the immune response. For example, a monocolonization of germ-free mice with the ubiquitous gut bacterium, Bacteroides fragilis, shows immunomodulatory activities of this bacterium, including correction of $\mathrm{T}$ cell deficiencies and $\mathrm{T}_{\mathrm{H}} 1 / \mathrm{T}_{\mathrm{H}} 2$ imbalances [98]. Segmented filamentous bacteria, the epithelial-associated bacteria, stimulate the maturation of proinflammatory IL-17A-producing T helper $17\left(\mathrm{~T}_{\mathrm{H}} 17\right)$ cells in the mouse small intestine [99,100]. Though considered as commensals, these bacteria have pathogenic properties and are referred to as pathobionts due to their capacity to induce a profound inflammatory state if an imbalance within the microbial population (also known as dysbiosis) occurs [101]. Microbial dysbiosis has been strongly linked to inflammatory bowel disease, a comorbidity of anxiety and depression [102]. Increased relative abundance of Escherichia coli and Enterococcus faecalis have been described to induce intestinal inflammation and bacterial-antigen specific cytokine production (IFN- $\gamma$ and IL-4) in a well-characterized murine colitis model IL10-/- [103]. Several Bacteroides genera have been recognized to be important for induction of inflammatory bowel disease in IL-10r2- $2^{-} \times \mathrm{Tg} f b r 2^{-1-}$ mouse colitis model [104]. Klebsiella pneumoniae and Proteus mirabilis, has been positively correlated with colitis in Tbx21 $1^{-/} \times \mathrm{Rag}^{-/-}$mouse inflammatory bowel disease model [105]. A common resident of the human mouth and gut, Fusobacterium nucleatum, when isolated from the inflamed gut of Crohn's 
disease patients evoked significantly greater TNF- $\alpha$ gene expression [106]. Finally, in experimental autoimmune encephalomyelitis, a mouse model of multiple sclerosis, germ-free or antibiotic-treated mice exhibited reduced inflammation and disease scores compared to conventional mice, suggesting a role for gut microbes on peripheral immune response, leading to brain inflammation [107,108]. Overall, these data suggest gut microbiota as an important immunomodulatory player in the gut-inflammation-brain crosstalk (Figure 1D).

\subsection{Gut Microbiota and Serotonin Production}

Recently, it has been shown that gut microbiota plays an important role in the regulation of the host serotonin levels [109]. Particular microbial metabolites, namely short chain fatty acids, have been shown to promote serotonin production from enterochromaffin cells in the epithelia via induction of TPH1 gene expression [109,110] (Figure 1D), most likely, due to their acidic pH. The effect of gut microbiota on intestinal serotonin levels expands beyond the gut. Plasma serotonin levels were in germ-free mice compared to conventional mice [111]. On the other hand, levels of hippocampal serotonin were significantly increased in germ-free and colonized germ-free mice compared to conventional mice [112]. However, a causation of differences in serotonin levels in germ-free mice still needs to be explained. Yano et al., further showed that SERT expression is increased in germ-free mice, suggesting its regulation by gut microbiota [109]. Indeed, SERT genotype has been linked to altered gut microbiota composition in young rats [88], where SERT knock out rats showed imbalanced microbial community dominated by members of the gut microbiota previously reported to be associated with a state of intestinal inflammation, and brain disorders including multiple depressive disorders [106,113-118]. Of note, the observed microbial imbalance was magnified when young rats were exposed to another stimulus, maternal separation [88], implying that the absence or domination of certain bacterial members in the gut of early-life stressed individuals may represent risk factors for the development of depression during later life stages.

Gut produced serotonin has been the target of several antidepressants, such as fluoxetine, which block its transport into the plasma via targeting SERT, thus named selective serotonin reuptake inhibitors (SSRIs). Administration of these antidepressants has been also successfully used as a treatment for gastrointestinal diseases, such as motility disorder and gastrointestinal bleeding [92,119], confirming comorbidity of these disorders, but exert a puzzling effect on the intestinal bacterial composition. Fluoxetine has an antimicrobial activity against Gram-positive bacteria such as Staphylococcus and Enterococcus and some anaerobic bacteria such as Clostridium difficile and Clostridium perfringens [3,120-122]. Similarly, Gram-negative bacteria such as Citrobacter spp., Pseudomonas aeruginosa, Klebsiella pneumoniae and Morganella morganii have been proven to be susceptible to SSRIs [120,123]. Notably, most of these bacteria are key players in induction of inflammation in the gut $[99,100,103-108]$. This suggests that through their antimicrobial activity, antidepressants might restore a balanced composition of the gut microbiota, and immune response, hence re-establish homeostasis at the gut-brain interphase. Deciphering the actual contribution of the antimicrobial effects of antidepressants for treatment of depression as well as determining the long-term consequences of these effects to gut microbiota composition and their implications to clinical outcomes is crucial for the development of microbiota derived therapeutic alternatives $[3,8,120,123]$.

Taken together, game-changing science is suggesting that depression is not only a result of a deficiency of serotonin and other neurotransmitters in the brain, but could rather start in the gut, via changing the microbiota composition through consumption of processed, nutrient poor diet, which in turn, leads to a state of inflammation, imbalanced levels of neurotransmitters, and eventually depression.

\subsection{The Dual Effect of Gut Microbiota and Its Metabolites in Depression}

Recently, changes in the composition of the gut microbiota have been associated with depressive-like behavior in humans and animal models [124,125]. Decreased levels of bacterial genera 
Bifidobacterium and Lactobacillus and increased levels of Streptococcaceae, Clostridiales, Eubacteriaceae and Ruminococcaceae, have been positively correlated with depressive symptoms $[124,126]$. Kelly et al. have shown that fecal microbiota transplantation from depressed patients to microbiota-depleted rats induced behavioral and physiological changes, leading to anxiety-like behaviors in the recipient animals, as well as alterations in tryptophan metabolism [125]. This suggests that changes in gut microbiota composition could play a causative role in the onset of depression.

Probiotic therapies have been applied in an attempt to correct for the possible absence of microbiota species capable of exhibiting suitable drivers of a "healthy" behavior. For example, the classical probiotics, Bifidobacteria and Lactobacilli, have been recently suggested as an alternative treatment for anxiety and depressive-like behaviors. Oral administration of a combination of Lactobacillus helveticus R0052 and Bifidobacterium longum R0175 (Probio'Stick ${ }^{\circledR}$, Lallemand, Montreal, QC, Canada) for a period of one month, has been reported to improve depression, anxiety, and lower the level of the stress hormone cortisol in humans $(n=26)$ [127]. A three-week consumption of a probiotic-containing milk drink that contained Lactobacillus casei Shirota, showed improved mood in healthy volunteers $(n=124)$ [128]. Similarly, when healthy male and female participants $(n=20)$ were administered with, either a placebo product or a mixture of several probiotics strains of Bifidobacteria and Lactobacilli over a period of 4 weeks, they exhibited substantially reduced reactivity to sad mood compared to control group [129]. Another small $(n=12)$ placebo-controlled study involving functional magnetic imaging has also demonstrated that a one-month consumption of a fermented food containing Bifidobacterium animalis subsp. lactis, Streptococcus thermophilus, Lactobacillus bulgaricus, and Lactococcus lactis subsp. lactis can influence brain activity as compared to baseline [130]. More recently, Lactobacillus reuteri has been described to reduce despair like behavior in mice by inhibiting elevated levels of IDO and reducing peripheral levels of kynurenine [131]. Whether the observed antidepressant effect of probiotics is due to their modulation of an intestinal inflammatory state, restoration of tryptophan metabolism, or reduction in serotonin turnover is still unclear.

Important to consider is indeed the influence of altered IDO activity and kynurenine pathway metabolism induced by gut microbiota [132]. In the germ-free state, microbial colonization induced the expression of genes encoding IDO, suggesting that gut microbiota activates this enzyme [17,96,132]. Moreover, other bacteria that flourish in an inflammatory environment, in particular Pseudomonas genera, can catabolize tryptophan into kynurenine via tryptophan 2,3-dioxygenase, $k y n A$ and kynurenine formamidase, $k y n B$ [133] (Figure 1D). Whether intestinal proinflammatory cytokines or any other metabolites have similar effect on induction of $k y n A$ and $k y n B$ expression in this bacterium, and subsequent increased levels of downstream metabolites, is still unknown. Additionally, in Pseudomonas aeruginosa, kynurenine acts as the main precursor of the Pseudomonas quinolone signal, a quorum-sensing signal that regulates numerous virulence genes in these bacteria [133]. This suggests that shifting tryptophan metabolism towards kynurenine during inflammation might result in inducing virulence in Pseudomonas, which in turn, causes imbalance in the microbial population, and disruption in the kynurenine and serotonin signaling systems, eventually leading to a state of depression.

Besides the kynurenine and serotonin arms within tryptophan metabolism, indole represents another important product in this metabolic pathway. Indole and its derivatives are exclusively produced by gut bacterial metabolism of tryptophan, via the tryptophanase (tnaA) enzyme [111,134,135]. In their recent rodent study, Jaglin et al. suggested that human subjects, who carry microbiota type dominated by species capable of overproducing indole may be more prone to develop anxiety and mood disorders [136]. The authors mimicked this situation by injecting indole in the cecum of conventional rats. The treated rats showed a dramatic decrease of motor activity, and higher levels of the indole-derivatives oxindole and isatin were detected in the brain. When germ-free rats were colonized with the indole-producing bacterial species E. coli to mimic a state of a chronic and moderate overproduction of indole and compared their behavior with that observed in germ-free counterparts mono-colonized with a mutant strain $E$. coli ${ }^{-\Delta t n a A}$, which is unable to produce indole, only rats colonized with wild-type strain showed anxiety-like behavior suggesting that indole and its 
metabolites might play a role in developing depression [136]. This study implies a direct mechanism by which the gut microbiota can influence the brain, and result in a state of depression, in this case via the production of the neuro-suppressive indole-derivatives; oxindole and isatin, which are products of gut epithelial or hepatic xenobiotic metabolizing enzymes (Figure 1D). However, another plausible mechanism could be through activation of the vagal afferent fibers in the intestinal mucosa either directly by indole or indirectly via secondary signals whose production could be triggered by indole. Another indole derivative, indole pyruvic acid, was shown to normalize the level of corticosterone in rodent model of depression and this effect was suggested to be due to the production of kynurenic acid in the brain [137]. Altogether, further studies are warranted for a comprehensive understanding of the mechanisms governing the beneficial or detrimental effects of gut microbiota and its metabolites on mood and behavior.

\section{Conclusions and Future Perspectives}

Given the mounting evidence over the past five years that microbiota play a key role at the gut-brain interphase shows a need to reveal the mechanisms that underpin this interaction in order to close the gap between therapeutic strategies and fundamental science. That the metabolites of the gut microbiota is evident to have a substantial effect on the regulation of immune response, tryptophan metabolism, and serotonin production, a diet characterized by nutrient-poor, energy-dense processed foods can well explain the strong link between depression and this multifaceted crosstalk. Restoring the gut microbiota composition via nutritional interventions could be an indirect strategic tool to treat depression. The use of selective dietary microbial growth substrates could be as beneficial but may result in long-lasting changes of the microbiome compared to the application of probiotic therapies.

Achieving a better understanding of the role of the complex triggers of depression requires further development of analytical approaches, including, metabolomics, to allow unraveling the metabolic dialogue between the microbiota and gut-brain axis. Equally important is the development of reliable models to decipher the complex interactions between the gut microbiota and its products, disruptions in immune response and dietary metabolism, all of which ultimately affect brain functionality, mood and behavior. The use of reductionist animal models has been very helpful in identifying underlying mechanisms in the host-microbe cross talk. However, it is increasingly clear that animal models fall short in translation to humans. Data acquired from large longitudinal human cohorts followed over long period of time, is essential to understand the real-world complexity of these interactions. Currently, there is an exponential growth of large bio-banks holding vast amounts of information about the same individual [138-140]. If combined with the state-of-art technologies including bacterial culturomics and individualized organs-on-chips to further understand the underlying causalities and mechanisms, only then we can bridge the gap between basic science and clinical practice and make major advances in personalized medicine. 


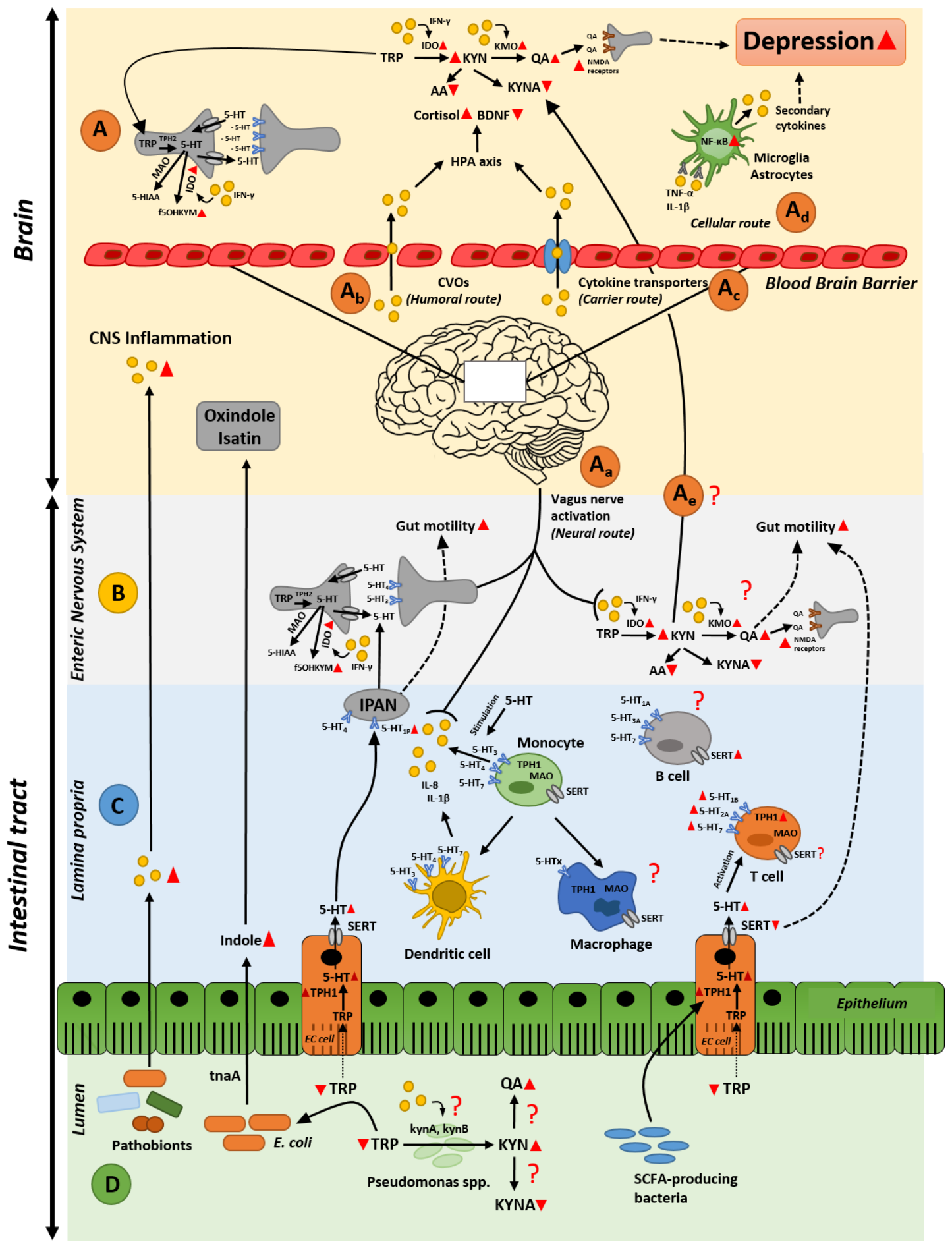

Figure 1. Gut microbiota remotely influences brain and depression. Potential routes by which the gut microbiota could govern the comorbidity of gut inflammation, disruption in tryptophan metabolism, and induction of depression. (A) Signaling mechanisms in the brain stimulated by inflammatory molecules in the gut; (B) molecular mechanisms by which the enteric nervous system affects gut motility and tryptophan metabolism during intestinal inflammation; (C) possible alterations of serotonin signaling in lamina propria resulting in gut hypermobility and inflammatory response; (D) influence of the gut microbiota and its secreted compounds on disruption on tryptophan metabolism and gut inflammation. Red triangles represent decreased/increased production or expression. Red question marks indicate missing links in this multi-faceted crosstalk. Dotted lines depict effects on gut motility. Abbreviations: 5-HIAA = 5-hydroxyindoleacetic acid; 5-HT = serotonin; 5 - $\mathrm{HT}_{\mathrm{x}}=$ serotonin receptors; 
$\mathrm{AA}=$ anthranilic acid; $\mathrm{BDNF}=$ brain-derived neurotrophic factor; CVOs = circumventricular organs; $\mathrm{EC}$ cell = enterochromaffin cell; HPA axis = hypothalamus-pituitary adrenal axis; IDO = indoleamine-2,3-dioxygenase; IFN- $\gamma=$ interferon $\gamma$; IPAN $=$ intrinsic primary afferent neuron; $\mathrm{KMO}=$ kynurenine-3-monooxygenase; $\mathrm{KYN}=$ kynurenine; $\mathrm{KYNA}=$ kynurenic acid; $\mathrm{MAO}=$ monoamine oxidase; NMDA receptors $=N$-methyl-D-aspartate receptors; $\mathrm{QA}=$ quinolinic acid; SCFAs = short-chain fatty acids; SERT = serotonin transporter; TNF- $\alpha=$ tumor necrosis factor $\alpha$; TPH1 = tryptophan hydroxylase; TRP = tryptophan; f5OHKM = formyl-5-hydroxykynuramine; kynA = tryptophan-2,3-dioxygenase from Pseudomonas spp.; kynB = kynurenine formamidase from Pseudomonas spp.; tnaA = tryptophanase.

Author Contributions: Conceptualization, B.W., S.E.A.; Writing-Original draft, B.W., S.E.A.; Writing-Review and Editing, B.W., S.E.A.; Funding Acquisition, S.E.A.

Funding: This research was funded by Rosalind Franklin Fellowships, co-funded by the European Union and University of Groningen.

Conflicts of Interest: The authors declare no conflicts of interest.

\section{References}

1. El Aidy, S.; Stilling, R.; Dinan, T.G.; Cryan, J.F. Microbiome to Brain: Unravelling the Multidirectional Axes of Communication. In Microbial Endocrinology: Interkingdom Signaling in Infectious Disease and Health. Advances in Experimental Medicine and Biology; Springer: Cham, Switzerland, 2016; pp. 301-336. ISBN 978-3-319-20214-3.

2. Shepherd, E.S.; DeLoache, W.C.; Pruss, K.M.; Whitaker, W.R.; Sonnenburg, J.L. An Exclusive Metabolic Niche Enables Strain Engraftment in the Gut Microbiota. Nature 2018, 557, 434-438. [CrossRef] [PubMed]

3. Maier, L.; Pruteanu, M.; Kuhn, M.; Zeller, G.; Telzerow, A.; Anderson, E.E.; Brochado, A.R.; Fernandez, K.C.; Dose, H.; Mori, H.; et al. Extensive Impact of Non-Antibiotic Drugs on Human Gut Bacteria. Nature 2018, 555, 623-628. [CrossRef] [PubMed]

4. Dodd, D.; Spitzer, M.H.; Van Treuren, W.; Merrill, B.D.; Hryckowian, A.J.; Higginbottom, S.K.; Le, A.; Cowan, T.M.; Nolan, G.P.; Fischbach, M.A.; et al. A Gut Bacterial Pathway Metabolizes Aromatic Amino Acids into Nine Circulating Metabolites. Nature 2017, 551, 648-652. [CrossRef] [PubMed]

5. Blander, J.M.; Longman, R.S.; Iliev, I.D.; Sonnenberg, G.F.; Artis, D. Regulation of Inflammation by Microbiota Interactions with the Host. Nat. Immunol. 2017, 18, 851-860. [CrossRef] [PubMed]

6. Berk, M.; Williams, L.J.; Jacka, F.N.; O’Neil, A.; Pasco, J.A.; Moylan, S.; Allen, N.B.; Stuart, A.L.; Hayley, A.C.; Byrne, M.L.; et al. So Depression Is an Inflammatory Disease, but Where Does the Inflammation Come From? BMC Med. 2013, 11, 200. [CrossRef] [PubMed]

7. Kiecolt-Glaser, J.K.; Derry, H.M.; Fagundes, C.P. Inflammation: Depression Fans the Flames and Feasts on the Heat. Am. J. Psychiatry 2015, 172, 1075-1091. [CrossRef] [PubMed]

8. Koopman, M.; El Aidy, S. Depressed Gut? The Microbiota-Diet-Inflammation Trialogue in Depression. Curr. Opin. Psychiatry 2017, 30, 369-377. [CrossRef] [PubMed]

9. World Health Organization. Depression. Available online: http://www.who.int/en/news-room/factsheets / detail/depression (accessed on 20 June 2018).

10. Raison, C.L.; Borisov, A.S.; Majer, M.; Drake, D.F.; Pagnoni, G.; Woolwine, B.J.; Vogt, G.J.; Massung, B.; Miller, A.H. Activation of Central Nervous System Inflammatory Pathways by Interferon-Alpha: Relationship to Monoamines and Depression. Biol. Psychiatry 2009, 65, 296-303. [CrossRef] [PubMed]

11. Thomas, J.; Khanam, R.; Vohora, D. Augmentation of Effect of Venlafaxine by Folic Acid in Behavioral Paradigms of Depression in Mice: Evidence of Serotonergic and pro-Inflammatory Cytokine Pathways. Pharmacol. Rep. 2016, 68, 396-403. [CrossRef] [PubMed]

12. Lebeña, A.; Vegas, O.; Gómez-Lázaro, E.; Arregi, A.; Garmendia, L.; Beitia, G.; Azpiroz, A. Melanoma Tumors Alter Proinflammatory Cytokine Production and Monoamine Brain Function, and Induce Depressive-like Behavior in Male Mice. Behav. Brain Res. 2014, 272, 83-92. [CrossRef] [PubMed] 
13. Wang, J.; Jia, Y.; Li, G.; Wang, B.; Zhou, T.; Zhu, L.; Chen, T.; Chen, Y. The Dopamine Receptor D3 Regulates Lipopolysaccharide-Induced Depressive-Like Behavior in Mice. Int. J. Neuropsychopharmacol. 2018, 21, 448-460. [CrossRef] [PubMed]

14. Coates, M.D.; Johnson, A.C.; Greenwood-van Meerveld, B.; Mawe, G.M. Effects of Serotonin Transporter Inhibition on Gastrointestinal Motility and Colonic Sensitivity in the Mouse. Neurogastroenterol. Motil. 2006, 18, 464-471. [CrossRef] [PubMed]

15. Coates, M.D.; Mahoney, C.R.; Linden, D.R.; Sampson, J.E.; Chen, J.; Blaszyk, H.; Crowell, M.D.; Sharkey, K.A.; Gershon, M.D.; Mawe, G.M. Molecular Defects in Mucosal Serotonin Content and Decreased Serotonin Reuptake Transporter in Ulcerative Colitis and Irritable Bowel Syndrome. Gastroenterology 2004, 126, 1657-1664. [CrossRef] [PubMed]

16. Kidd, M.; Gustafsson, B.I.; Drozdov, I.; Modlin, I.M. IL1 $\beta$ - and LPS-Induced Serotonin Secretion Is Increased in EC Cells Derived from Crohn's Disease. Neurogastroenterol. Motil. 2009, 21, 439-450. [CrossRef] [PubMed]

17. El Aidy, S.; Dinan, T.G.; Cryan, J.F. Immune Modulation of the Brain-Gut-Microbe Axis. Front. Microbiol. 2014, 5, 146. [CrossRef] [PubMed]

18. Linden, D.R.; Chen, J.-X.; Gershon, M.D.; Sharkey, K.A.; Mawe, G.M. Serotonin Availability Is Increased in Mucosa of Guinea Pigs with TNBS-Induced Colitis. Am. J. Physiol. Liver Physiol. 2003, 285, G207-G216. [CrossRef] [PubMed]

19. Mawe, G.M.; Hoffman, J.M. Serotonin Signalling in the Gut-functions, Dysfunctions and Therapeutic Targets. Nat. Rev. Gastroenterol. Hepatol. 2013, 10, 473-486. [CrossRef] [PubMed]

20. Dantzer, R. Cytokine, Sickness Behavior, and Depression. Immunol. Allergy Clin. N. Am. 2009, $29,247-264$. [CrossRef] [PubMed]

21. Van Heesch, F. Inflammation-Induced Depression. Studying the Role of Proinflammatory Cytokines in Anhedonia; Utrecht University: Utrecht, The Netherlands, 2014.

22. Capuron, L.; Miller, A.H. Immune System to Brain Signaling: Neuropsychopharmacological Implications. Pharmacol. Ther. 2011, 130, 226-238. [CrossRef] [PubMed]

23. D'Mello, C.; Swain, M.G. Immune-to-Brain Communication Pathways in Inflammation-Associated Sickness and Depression. In Inflammation-Associated Depression: Evidence, Mechanisms and Implications. Current Topics in Behavioral Neurosciences; Springer: Cham, Switzerland, 2016; pp. 73-94.

24. Ransohoff, R.M.; Kivisäkk, P.; Kidd, G. Three or More Routes for Leukocyte Migration into the Central Nervous System. Nat. Rev. Immunol. 2003, 3, 569-581. [CrossRef] [PubMed]

25. Dantzer, R.; O'Connor, J.C.; Freund, G.G.; Johnson, R.W.; Kelley, K.W. From Inflammation to Sickness and Depression: When the Immune System Subjugates the Brain. Nat. Rev. Neurosci. 2008, 9, 46-56. [CrossRef] [PubMed]

26. Banks, W.A. The Blood-brain Barrier as a Regulatory Interface in the Gut-brain Axes. Physiol. Behav. 2006, 89, 472-476. [CrossRef] [PubMed]

27. Jensen, C.J.; Massie, A.; De Keyser, J. Immune Players in the CNS: The Astrocyte. J. Neuroimmune Pharmacol. 2013, 8, 824-839. [CrossRef] [PubMed]

28. Yang, I.; Han, S.J.; Kaur, G.; Crane, C.; Parsa, A.T. The Role of Microglia in Central Nervous System Immunity and Glioma Immunology. J. Clin. Neurosci. 2010, 17, 6-10. [CrossRef] [PubMed]

29. Nadeau, S.; Rivest, S. Effects of Circulating Tumor Necrosis Factor on the Neuronal Activity and Expression of the Genes Encoding the Tumor Necrosis Factor Receptors (P55 and P75) in the Rat Brain: A View from the Blood-brain Barrier. Neuroscience 1999, 93, 1449-1464. [CrossRef]

30. Rivest, S.; Lacroix, S.; Vallières, L.; Nadeau, S.; Zhang, J.; Laflamme, N. How the Blood Talks to the Brain Parenchyma and the Paraventricular Nucleus of the Hypothalamus during Systemic Inflammatory and Infectious Stimuli. Proc. Soc. Exp. Biol. Med. 2000, 223, 22-38. [CrossRef] [PubMed]

31. Capuron, L.; Gumnick, J.F.; Musselman, D.L.; Lawson, D.H.; Reemsnyder, A.; Nemeroff, C.B.; Miller, A.H. Neurobehavioral Effects of Interferon- $\alpha$ in Cancer Patients Phenomenology and Paroxetine Responsiveness of Symptom Dimensions. Neuropsychopharmacology 2002, 26, 643-652. [CrossRef]

32. Howren, M.B.; Lamkin, D.M.; Suls, J. Associations of Depression with C-Reactive Protein, IL-1, and IL-6: A Meta-Analysis. Psychosom. Med. 2009, 71, 171-186. [CrossRef] [PubMed]

33. Kałużna-Czaplińska, J.; Gątarek, P.; Chirumbolo, S.; Chartrand, M.S.; Bjørklund, G. How Important Is Tryptophan in Human Health? Crit. Rev. Food Sci. Nutr. 2017, 1-17. [CrossRef] [PubMed] 
34. Le Floc'h, N.; Otten, W.; Merlot, E. Tryptophan Metabolism, from Nutrition to Potential Therapeutic Applications. Amino Acids 2011, 41, 1195-1205. [CrossRef] [PubMed]

35. Ruddick, J.P.; Evans, A.K.; Nutt, D.J.; Lightman, S.L.; Rook, G.A.W.; Lowry, C.A. Tryptophan Metabolism in the Central Nervous System: Medical Implications. Expert Rev. Mol. Med. 2006, 8, 1-27. [CrossRef] [PubMed]

36. Kennedy, P.J.; Cryan, J.F.; Dinan, T.G.; Clarke, G. Kynurenine Pathway Metabolism and the Microbiota-Gut-Brain Axis. Neuropharmacology 2017, 112, 399-412. [CrossRef] [PubMed]

37. Spiller, R. Serotonin and GI Clinical Disorders. Neuropharmacology 2008, 55, 1072-1080. [CrossRef] [PubMed]

38. Gershon, M.D. 5-Hydroxytryptamine (Serotonin) in the Gastrointestinal Tract. Curr. Opin. Endocrinol. Diabetes Obes. 2013, 20, 14-21. [CrossRef] [PubMed]

39. Nguyen, N.T.; Nakahama, T.; Le, D.H.; Van Son, L.; Chu, H.H.; Kishimoto, T. Aryl Hydrocarbon Receptor and Kynurenine: Recent Advances in Autoimmune Disease Research. Front. Immunol. 2014, 5, 551. [CrossRef] [PubMed]

40. O'Mahony, S.M.; Clarke, G.; Borre, Y.E.; Dinan, T.G.; Cryan, J.F. Serotonin, Tryptophan Metabolism and the Brain-Gut-Microbiome Axis. Behav. Brain Res. 2015, 277, 32-48. [CrossRef] [PubMed]

41. Badawy, A.A.-B. Tryptophan Availability for Kynurenine Pathway Metabolism across the Life Span: Control Mechanisms and Focus on Aging, Exercise, Diet and Nutritional Supplements. Neuropharmacology 2017, 112, 248-263. [CrossRef] [PubMed]

42. Richard, D.M.; Dawes, M.A.; Mathias, C.W.; Acheson, A.; Hill-Kapturczak, N.; Dougherty, D.M. L-Tryptophan: Basic Metabolic Functions, Behavioral Research and Therapeutic Indications. Int. J. Tryptophan Res. 2009, 2, 45-60. [CrossRef] [PubMed]

43. Keszthelyi, D.; Troost, F.J.; Jonkers, D.M.; van Donkelaar, E.L.; Dekker, J.; Buurman, W.A.; Masclee, A.A. Does Acute Tryptophan Depletion Affect Peripheral Serotonin Metabolism in the Intestine? Am. J. Clin. Nutr. 2012, 95, 603-608. [CrossRef] [PubMed]

44. Gál, E.M.; Sherman, A.D. L-Kynurenine: Its Synthesis and Possible Regulatory Function in Brain. Neurochem. Res. 1980, 5, 223-239. [CrossRef] [PubMed]

45. Catena-Dell'Osso, M.; Rotella, F.; Dell'Osso, A.; Fagiolini, A.; Marazziti, D. Inflammation, Serotonin and Major Depression. Curr. Drug Targets 2013, 14, 571-577. [CrossRef] [PubMed]

46. Salter, M.; Pogson, C.I. The Role of Tryptophan 2,3-Dioxygenase in the Hormonal Control of Tryptophan Metabolism in Isolated Rat Liver Cells. Effects of Glucocorticoids and Experimental Diabetes. Biochem. J. 1985, 229, 499-504. [CrossRef] [PubMed]

47. Yeung, A.W.S.; Terentis, A.C.; King, N.J.C.; Thomas, S.R. Role of Indoleamine 2,3-Dioxygenase in Health and Disease. Clin. Sci. 2015, 129, 601-672. [CrossRef] [PubMed]

48. Jurgens, B.; Hainz, U.; Fuchs, D.; Felzmann, T.; Heitger, A. Interferon- $\gamma$-Triggered Indoleamine 2,3-Dioxygenase Competence in Human Monocyte-Derived Dendritic Cells Induces Regulatory Activity in Allogeneic T Cells. Blood 2009, 114, 3235-3243. [CrossRef] [PubMed]

49. Dantzer, R. Role of the Kynurenine Metabolism Pathway in Inflammation-Induced Depression: Preclinical Approaches. In Inflammation-Associated Depression: Evidence, Mechanisms and Implications. Current Topics in Behavioral Neurosciences; Springer: Cham, Switzerland, 2016; pp. 117-138. ISBN 978-3-319-51152-8.

50. Pertz, H.; Back, W. Synthesis and Resolution of Chiral Ring-Opened Serotonin Analogs of the 5-Hydroxykynuramine Type. Pharm. Acta Helv. 1988, 63, 128-131. [PubMed]

51. Jeon, S.W.; Kim, Y.-K. Inflammation-Induced Depression: Its Pathophysiology and Therapeutic Implications. J. Neuroimmunol. 2017, 313, 92-98. [CrossRef] [PubMed]

52. Keszthelyi, D.; Troost, F.J.; Masclee, A.A.M. Understanding the Role of Tryptophan and Serotonin Metabolism in Gastrointestinal Function. Neurogastroenterol. Motil. 2009, 21, 1239-1249. [CrossRef] [PubMed]

53. Fukui, S.; Schwarcz, R.; Rapoport, S.I.; Takada, Y.; Smith, Q.R. Blood-Brain Barrier Transport of Kynurenines: Implications for Brain Synthesis and Metabolism. J. Neurochem. 1991, 56, 2007-2017. [CrossRef] [PubMed]

54. Savitz, J.; Drevets, W.C.; Wurfel, B.E.; Ford, B.N.; Bellgowan, P.S.F.; Victor, T.A.; Bodurka, J.; Teague, T.K.; Dantzer, R. Reduction of Kynurenic Acid to Quinolinic Acid Ratio in Both the Depressed and Remitted Phases of Major Depressive Disorder. Brain Behav. Immun. 2015, 46, 55-59. [CrossRef] [PubMed]

55. Bay-Richter, C.; Linderholm, K.R.; Lim, C.K.; Samuelsson, M.; Träskman-Bendz, L.; Guillemin, G.J.; Erhardt, S.; Brundin, L. A Role for Inflammatory Metabolites as Modulators of the Glutamate N-Methyl-D-Aspartate Receptor in Depression and Suicidality. Brain Behav. Immun. 2015, 43, 110-117. [CrossRef] [PubMed] 
56. Bryleva, E.Y.; Brundin, L. Kynurenine Pathway Metabolites and Suicidality. Neuropharmacology 2017, 112, 324-330. [CrossRef] [PubMed]

57. Wurfel, B.E.; Drevets, W.C.; Bliss, S.A.; McMillin, J.R.; Suzuki, H.; Ford, B.N.; Morris, H.M.; Teague, T.K.; Dantzer, R.; Savitz, J.B. Serum Kynurenic Acid Is Reduced in Affective Psychosis. Transl. Psychiatry 2017, 7, e1115. [CrossRef] [PubMed]

58. Connor, T.J.; Starr, N.; O'Sullivan, J.B.; Harkin, A. Induction of Indolamine 2,3-Dioxygenase and Kynurenine 3-Monooxygenase in Rat Brain Following a Systemic Inflammatory Challenge: A Role for IFN- $\gamma$ ? Neurosci. Lett. 2008, 441, 29-34. [CrossRef] [PubMed]

59. Molteni, R.; Macchi, F.; Zecchillo, C.; Dell'Agli, M.; Colombo, E.; Calabrese, F.; Guidotti, G.; Racagni, G.; Riva, M.A. Modulation of the Inflammatory Response in Rats Chronically Treated with the Antidepressant Agomelatine. Eur. Neuropsychopharmacol. 2013, 23, 1645-1655. [CrossRef] [PubMed]

60. Erhardt, S.; Lim, C.K.; Linderholm, K.R.; Janelidze, S.; Lindqvist, D.; Samuelsson, M.; Lundberg, K.; Postolache, T.T.; Träskman-Bendz, L.; Guillemin, G.J.; et al. Connecting Inflammation with Glutamate Agonism in Suicidality. Neuropsychopharmacology 2013, 38, 743-752. [CrossRef] [PubMed]

61. Husi, H. NMDA Receptors, Neural Pathways, and Protein Interaction Databases. Int. Rev. Neurobiol. 2004, 61, 49-77. [CrossRef] [PubMed]

62. Giaroni, C.; Zanetti, E.; Chiaravalli, A.M.; Albarello, L.; Dominioni, L.; Capella, C.; Lecchini, S.; Frigo, G. Evidence for a Glutamatergic Modulation of the Cholinergic Function in the Human Enteric Nervous System via NMDA Receptors. Eur. J. Pharmacol. 2003, 476, 63-69. [CrossRef]

63. Kirchgessner, A. Glutamate in the Enteric Nervous System. Curr. Opin. Pharmacol. 2001, 1, 591-596. [CrossRef]

64. Zhou, Q.; Nicholas Verne, G. NMDA Receptors and Colitis: Basic Science and Clinical Implications. Rev. Analg. 2008, 10, 33-43. [CrossRef] [PubMed]

65. Varga, G.; Érces, D.; Fazekas, B.; Fülöp, M.; Kovács, T.; Kaszaki, J.; Fülöp, F.; Vécsei, L.; Boros, M. N-Methyl-D-Aspartate Receptor Antagonism Decreases Motility and Inflammatory Activation in the Early Phase of Acute Experimental Colitis in the Rat. Neurogastroenterol. Motil. 2010, 22, 217-e68. [CrossRef] [PubMed]

66. Coutinho, S.V.; Meller, S.T.; Gebhart, G.F. Intracolonic Zymosan Produces Visceral Hyperalgesia in the Rat That Is Mediated by Spinal NMDA and Non-NMDA Receptors. Brain Res. 1996, 736, 7-15. [CrossRef]

67. Berger, M.; Gray, J.A.; Roth, B.L. The Expanded Biology of Serotonin. Annu. Rev. Med. 2009, 60, 355-366. [CrossRef] [PubMed]

68. Wade, P.R.; Tamir, H.; Kirchgessner, A.L.; Gershon, M.D. Analysis of the Role of 5-HT in the Enteric Nervous System Using Anti-Idiotopic Antibodies to 5-HT Receptors. Am. J. Physiol. Liver Physiol. 1994, 266, G403-G416. [CrossRef] [PubMed]

69. Gershon, M.D.; Ross, L.L. Studies on the Relationship of 5-Hydroxytryptamine and the Enterochromaffin Cell to Anaphylactic Shock in Mice. J. Exp. Med. 1962, 115, 367-382. [CrossRef] [PubMed]

70. Coleman, J.A.; Green, E.M.; Gouaux, E. X-Ray Structures and Mechanism of the Human Serotonin Transporter. Nature 2016, 532, 334-339. [CrossRef] [PubMed]

71. Murphy, D.L.; Lerner, A.; Rudnick, G.; Lesch, K.-P. Serotonin Transporter: Gene, Genetic Disorders, and Pharmacogenetics. Mol. Interv. 2004, 4, 109-123. [CrossRef] [PubMed]

72. Hannon, J.; Hoyer, D. Molecular Biology of 5-HT Receptors. Behav. Brain Res. 2008, 195, 198-213. [CrossRef] [PubMed]

73. Tutton, P.J. The Influence of Serotonin on Crypt Cell Proliferation in the Jejunum of Rat. Virchows Arch. B Cell Pathol. 1974, 16, 79-87. [CrossRef] [PubMed]

74. Gershon, M.D. Nerves, Reflexes, and the Enteric Nervous System. J. Clin. Gastroenterol. 2005, 39, S184-S193. [CrossRef] [PubMed]

75. Mazzia, C.; Hicks, G.; Clerc, N. Neuronal Location of 5-Hydroxytryptamine 3 Receptor-like Immunoreactivity in the Rat Colon. Neuroscience 2003, 116, 1033-1041. [CrossRef]

76. Grider, J.R. Desensitization of the Peristaltic Reflex Induced by Mucosal Stimulation with the Selective 5-HT 4 Agonist Tegaserod. Am. J. Physiol. Liver Physiol. 2006, 290, G319-G327. [CrossRef] [PubMed]

77. Pan, H.; Galligan, J.J. 5- $\mathrm{HT}_{1 \mathrm{~A}}$ and 5- $\mathrm{HT}_{4}$ Receptors Mediate Inhibition and Facilitation of Fast Synaptic Transmission in Enteric Neurons. Am. J. Physiol. 1994, 266, G230-8. [CrossRef] [PubMed] 
78. Galligan, J.J.; Pan, H.; Messori, E. Signalling Mechanism Coupled to 5-Hydroxytryptamine 4 Receptor-Mediated Facilitation of Fast Synaptic Transmission in the Guinea-Pig Ileum Myenteric Plexus. Neurogastroenterol. Motil. 2003, 15, 523-529. [CrossRef] [PubMed]

79. Baganz, N.L.; Blakely, R.D. A Dialogue between the Immune System and Brain, Spoken in the Language of Serotonin. ACS Chem. Neurosci. 2013, 4, 48-63. [CrossRef] [PubMed]

80. Herr, N.; Bode, C.; Duerschmied, D. The Effects of Serotonin in Immune Cells. Front. Cardiovasc. Med. 2017, 4, 48. [CrossRef] [PubMed]

81. Leon-Ponte, M.; Ahern, G.P.; O'Connell, P.J. Serotonin Provides an Accessory Signal to Enhance T-Cell Activation by Signaling through the 5-HT 7 Receptor. Blood 2007, 109, 3139-3146. [CrossRef] [PubMed]

82. Medina-Martel, M.; Urbina, M.; Fazzino, F.; Lima, L. Serotonin Transporter in Lymphocytes of Rats Exposed to Physical Restraint Stress. Neuroimmunomodulation 2013, 20, 361-367. [CrossRef] [PubMed]

83. Meredith, E.J.; Holder, M.J.; Chamba, A.; Challa, A.; Drake-Lee, A.; Bunce, C.M.; Drayson, M.T.; Pilkington, G.; Blakely, R.D.; Dyer, M.J.S.; et al. The Serotonin Transporter (SLC6A4) Is Present in B-Cell Clones of Diverse Malignant Origin: Probing a Potential Anti-Tumor Target for Psychotropics. FASEB J. 2005, 19, 1187-1189. [CrossRef] [PubMed]

84. Idzko, M.; Panther, E.; Stratz, C.; Muller, T.; Bayer, H.; Zissel, G.; Durk, T.; Sorichter, S.; Di Virgilio, F.; Geissler, M.; et al. The Serotoninergic Receptors of Human Dendritic Cells: Identification and Coupling to Cytokine Release. J. Immunol. 2004, 172, 6011-6019. [CrossRef] [PubMed]

85. Dürk, T.; Panther, E.; Müller, T.; Sorichter, S.; Ferrari, D.; Pizzirani, C.; Di Virgilio, F.; Myrtek, D.; Norgauer, J.; Idzko, M. 5-Hydroxytryptamine Modulates Cytokine and Chemokine Production in LPS-Primed Human Monocytes via Stimulation of Different 5-HTR Subtypes. Int. Immunol. 2005, 17, 599-606. [CrossRef] [PubMed]

86. Fiorica-Howells, E.; Liu, M.-T.; Ponimaskin, E.G.; Li, Z.-S.; Compan, V.; Hen, R.; Gingrich, J.A.; Gershon, M.D. Distribution of $5-\mathrm{HT}_{4}$ Receptors in Wild-Type Mice and Analysis of Intestinal Motility in 5- $\mathrm{HT}_{4}$ Knockout Mice. Gastroenterology 2003, 124, A342. [CrossRef]

87. Compan, V. Attenuated Response to Stress and Novelty and Hypersensitivity to Seizures in 5-HT 4 Receptor Knock-Out Mice. J. Neurosci. 2004, 24, 412-419. [CrossRef] [PubMed]

88. El Aidy, S.; Ramsteijn, A.S.; Dini-Andreote, F.; van Eijk, R.; Houwing, D.J.; Salles, J.F.; Olivier, J.D.A. Serotonin Transporter Genotype Modulates the Gut Microbiota Composition in Young Rats, an Effect Augmented by Early Life Stress. Front. Cell. Neurosci. 2017, 11, 222. [CrossRef] [PubMed]

89. Chen, J.J.; Li, Z.; Pan, H.; Murphy, D.L.; Tamir, H.; Koepsell, H.; Gershon, M.D. Maintenance of Serotonin in the Intestinal Mucosa and Ganglia of Mice That Lack the High-Affinity Serotonin Transporter: Abnormal Intestinal Motility and the Expression of Cation Transporters. J. Neurosci. 2001, 21, 6348-6361. [CrossRef] [PubMed]

90. Gershon, M.D.; Tack, J. The Serotonin Signaling System: From Basic Understanding To Drug Development for Functional GI Disorders. Gastroenterology 2007, 132, 397-414. [CrossRef] [PubMed]

91. Canli, T.; Lesch, K.-P. Long Story Short: The Serotonin Transporter in Emotion Regulation and Social Cognition. Nat. Neurosci. 2007, 10, 1103-1109. [CrossRef] [PubMed]

92. Scheerens, C.; Tack, J.; Rommel, N. Buspirone, a New Drug for the Management of Patients with Ineffective Esophageal Motility? United Eur. Gastroenterol. J. 2015, 3, 261-265. [CrossRef] [PubMed]

93. Di Sabatino, A.; Giuffrida, P.; Vanoli, A.; Luinetti, O.; Manca, R.; Biancheri, P.; Bergamaschi, G.; Alvisi, C.; Pasini, A.; Salvatore, C.; et al. Increase in Neuroendocrine Cells in the Duodenal Mucosa of Patients with Refractory Celiac Disease. Am. J. Gastroenterol. 2014, 109, 258-269. [CrossRef] [PubMed]

94. Bruce-Keller, A.J.; Salbaum, J.M.; Berthoud, H.-R. Harnessing Gut Microbes for Mental Health: Getting From Here to There. Biol. Psychiatry 2018, 83, 214-223. [CrossRef] [PubMed]

95. Round, J.L.; O'Connell, R.M.; Mazmanian, S.K. Coordination of Tolerogenic Immune Responses by the Commensal Microbiota. J. Autoimmun. 2010, 34. [CrossRef] [PubMed]

96. El Aidy, S.; van Baarlen, P.; Derrien, M.; Lindenbergh-Kortleve, D.J.; Hooiveld, G.; Levenez, F.; Doré, J.; Dekker, J.; Samsom, J.N.; Nieuwenhuis, E.E.S.; et al. Temporal and Spatial Interplay of Microbiota and Intestinal Mucosa Drive Establishment of Immune Homeostasis in Conventionalized Mice. Mucosal Immunol. 2012, 5, 567-579. [CrossRef] [PubMed] 
97. El Aidy, S.; Derrien, M.; Aardema, R.; Hooiveld, G.; Richards, S.E.; Dane, A.; Dekker, J.; Vreeken, R.; Levenez, F.; Doré, J.; et al. Transient Inflammatory-like State and Microbial Dysbiosis Are Pivotal in Establishment of Mucosal Homeostasis during Colonisation of Germ-Free Mice. Benef. Microbes 2014, 5, 67-77. [CrossRef] [PubMed]

98. Mazmanian, S.K.; Liu, C.H.; Tzianabos, A.O.; Kasper, D.L. An Immunomodulatory Molecule of Symbiotic Bacteria Directs Maturation of the Host Immune System. Cell 2005, 122, 107-118. [CrossRef] [PubMed]

99. Gaboriau-Routhiau, V.; Rakotobe, S.; Lécuyer, E.; Mulder, I.; Lan, A.; Bridonneau, C.; Rochet, V.; Pisi, A.; De Paepe, M.; Brandi, G.; et al. The Key Role of Segmented Filamentous Bacteria in the Coordinated Maturation of Gut Helper T Cell Responses. Immunity 2009, 31, 677-689. [CrossRef] [PubMed]

100. Ivanov, I.I.; Atarashi, K.; Manel, N.; Brodie, E.L.; Shima, T.; Karaoz, U.; Wei, D.; Goldfarb, K.C.; Santee, C.A.; Lynch, S.V.; et al. Induction of Intestinal Th17 Cells by Segmented Filamentous Bacteria. Cell 2009, 139, 485-498. [CrossRef] [PubMed]

101. Chow, J.; Mazmanian, S.K. A Pathobiont of the Microbiota Balances Host Colonization and Intestinal Inflammation. Cell Host Microbe 2010, 7, 265-276. [CrossRef] [PubMed]

102. Emge, J.R.; Huynh, K.; Miller, E.N.; Kaur, M.; Reardon, C.; Barrett, K.E.; Gareau, M.G. Modulation of the Microbiota-Gut-Brain Axis by Probiotics in a Murine Model of Inflammatory Bowel Disease. Am. J. Physiol. Liver Physiol. 2016, 310, G989-G998. [CrossRef] [PubMed]

103. Kim, S.C.; Tonkonogy, S.L.; Albright, C.A.; Tsang, J.; Balish, E.J.; Braun, J.; Huycke, M.M.; Sartor, R.B. Variable Phenotypes of Enterocolitis in Interleukin 10-Deficient Mice Monoassociated with Two Different Commensal Bacteria. Gastroenterology 2005, 128, 891-906. [CrossRef] [PubMed]

104. Bloom, S.M.; Bijanki, V.N.; Nava, G.M.; Sun, L.; Malvin, N.P.; Donermeyer, D.L.; Dunne, W.M.; Allen, P.M.; Stappenbeck, T.S. Commensal Bacteroides Species Induce Colitis in Host-Genotype-Specific Fashion in a Mouse Model of Inflammatory Bowel Disease. Cell Host Microbe 2011, 9, 390-403. [CrossRef] [PubMed]

105. Garrett, W.S.; Gallini, C.A.; Yatsunenko, T.; Michaud, M.; DuBois, A.; Delaney, M.L.; Punit, S.; Karlsson, M.; Bry, L.; Glickman, J.N.; et al. Enterobacteriaceae Act in Concert with the Gut Microbiota to Induce Spontaneous and Maternally Transmitted Colitis. Cell Host Microbe 2010, 8, 292-300. [CrossRef] [PubMed]

106. Dharmani, P.; Strauss, J.; Ambrose, C.; Allen-Vercoe, E.; Chadee, K. Fusobacterium Nucleatum Infection of Colonic Cells Stimulates MUC2 Mucin and Tumor Necrosis Factor Alpha. Infect. Immun. 2011, 79, 2597-2607. [CrossRef] [PubMed]

107. Lee, Y.K.; Menezes, J.S.; Umesaki, Y.; Mazmanian, S.K. Proinflammatory T-Cell Responses to Gut Microbiota Promote Experimental Autoimmune Encephalomyelitis. Proc. Natl. Acad. Sci. USA 2011, 108, 4615-4622. [CrossRef] [PubMed]

108. Ochoa-Reparaz, J.; Mielcarz, D.W.; Ditrio, L.E.; Burroughs, A.R.; Foureau, D.M.; Haque-Begum, S.; Kasper, L.H. Role of Gut Commensal Microflora in the Development of Experimental Autoimmune Encephalomyelitis. J. Immunol. 2009, 183, 6041-6050. [CrossRef] [PubMed]

109. Yano, J.M.; Yu, K.; Donaldson, G.P.; Shastri, G.G.; Ann, P.; Ma, L.; Nagler, C.R.; Ismagilov, R.F.; Mazmanian, S.K.; Hsiao, E.Y. Indigenous Bacteria from the Gut Microbiota Regulate Host Serotonin Biosynthesis. Cell 2015, 161, 264-276. [CrossRef] [PubMed]

110. Reigstad, C.S.; Salmonson, C.E.; Rainey, J.F.; Szurszewski, J.H.; Linden, D.R.; Sonnenburg, J.L.; Farrugia, G.; Kashyap, P.C. Gut Microbes Promote Colonic Serotonin Production through an Effect of Short-Chain Fatty Acids on Enterochromaffin Cells. FASEB J. 2015, 29, 1395-1403. [CrossRef] [PubMed]

111. Wikoff, W.R.; Anfora, A.T.; Liu, J.; Schultz, P.G.; Lesley, S.A.; Peters, E.C.; Siuzdak, G. Metabolomics Analysis Reveals Large Effects of Gut Microflora on Mammalian Blood Metabolites. Proc. Natl. Acad. Sci. USA 2009, 106, 3698-3703. [CrossRef] [PubMed]

112. Clarke, G.; Grenham, S.; Scully, P.; Fitzgerald, P.; Moloney, R.D.; Shanahan, F.; Dinan, T.G.; Cryan, J.F. The Microbiome-Gut-Brain Axis during Early Life Regulates the Hippocampal Serotonergic System in a Sex-Dependent Manner. Mol. Psychiatry 2013, 18, 666-673. [CrossRef] [PubMed]

113. Rooks, M.G.; Veiga, P.; Wardwell-Scott, L.H.; Tickle, T.; Segata, N.; Michaud, M.; Gallini, C.A.; Beal, C.; van Hylckama-Vlieg, J.E.; Ballal, S.A.; et al. Gut Microbiome Composition and Function in Experimental Colitis during Active Disease and Treatment-Induced Remission. ISME J. 2014, 8, 1403-1417. [CrossRef] [PubMed] 
114. Robertson, B.R. Mucispirillum Schaedleri Gen. Nov., Sp. Nov., a Spiral-Shaped Bacterium Colonizing the Mucus Layer of the Gastrointestinal Tract of Laboratory Rodents. Int. J. Syst. Evol. Microbiol. 2005, 55, 1199-1204. [CrossRef] [PubMed]

115. Berry, D.; Schwab, C.; Milinovich, G.; Reichert, J.; Ben Mahfoudh, K.; Decker, T.; Engel, M.; Hai, B.; Hainzl, E.; Heider, S.; et al. Phylotype-Level 16S RRNA Analysis Reveals New Bacterial Indicators of Health State in Acute Murine Colitis. ISME J. 2012, 6, 2091-2106. [CrossRef] [PubMed]

116. Carbonero, F.; Benefiel, A.C.; Gaskins, H.R. Contributions of the Microbial Hydrogen Economy to Colonic Homeostasis. Nat. Rev. Gastroenterol. Hepatol. 2012, 9, 504-518. [CrossRef] [PubMed]

117. Kostic, A.D.; Chun, E.; Robertson, L.; Glickman, J.N.; Gallini, C.A.; Michaud, M.; Clancy, T.E.; Chung, D.C.; Lochhead, P.; Hold, G.L.; et al. Fusobacterium Nucleatum Potentiates Intestinal Tumorigenesis and Modulates the Tumor-Immune Microenvironment. Cell Host Microbe 2013, 14, 207-215. [CrossRef] [PubMed]

118. Strauss, J.; Kaplan, G.G.; Beck, P.L.; Rioux, K.; Panaccione, R.; DeVinney, R.; Lynch, T.; Allen-Vercoe, E. Invasive Potential of Gut Mucosa-Derived Fusobacterium Nucleatum Positively Correlates with IBD Status of the Host. Inflamm. Bowel Dis. 2011, 17, 1971-1978. [CrossRef] [PubMed]

119. Wang, Y.-P.; Chen, Y.-T.; Tsai, C.-F.; Li, S.-Y.; Luo, J.-C.; Wang, S.-J.; Tang, C.-H.; Liu, C.-J.; Lin, H.-C.; Lee, F.-Y.; et al. Short-Term Use of Serotonin Reuptake Inhibitors and Risk of Upper Gastrointestinal Bleeding. Am. J. Psychiatry 2014, 171, 54-61. [CrossRef] [PubMed]

120. Macedo, D.; Filho, A.J.M.C.; Soares de Sousa, C.N.; Quevedo, J.; Barichello, T.; Júnior, H.V.N.; Freitas de Lucena, D. Antidepressants, Antimicrobials or Both? Gut Microbiota Dysbiosis in Depression and Possible Implications of the Antimicrobial Effects of Antidepressant Drugs for Antidepressant Effectiveness. J. Affect. Disord. 2017, 208, 22-32. [CrossRef] [PubMed]

121. Coban, A.Y.; Tanriverdi Cayci, Y.; Keleş Uludağ, S.; Durupinar, B. Investigation of Antibacterial Activity of Sertralin. Mikrobiyol. Bul. 2009, 43, 651-656. [PubMed]

122. Munoz-Bellido, J.; Munoz-Criado, S.; Garcì-Rodrìguez, J. Antimicrobial Activity of Psychotropic Drugs: Selective Serotonin Reuptake Inhibitors. Int. J. Antimicrob. Agents 2000, 14, 177-180. [CrossRef]

123. Kruszewska, H.; Zaręba, T.; Tyski, S. Examination of Antimicrobial Activity of Selected Non-Antibiotic Medicinal Preparations. Acta Pol. Pharm. Drug Res. 2012, 69, 1368-1371.

124. Cenit, M.C.; Sanz, Y.; Codoñer-Franch, P. Influence of Gut Microbiota on Neuropsychiatric Disorders. World J. Gastroenterol. 2017, 23, 5486-5498. [CrossRef] [PubMed]

125. Kelly, J.R.; Borre, Y.; O’Brien, C.; Patterson, E.; El Aidy, S.; Deane, J.; Kennedy, P.J.; Beers, S.; Scott, K.; Moloney, G.; et al. Transferring the Blues: Depression-Associated Gut Microbiota Induces Neurobehavioural Changes in the Rat. J. Psychiatr. Res. 2016, 82, 109-118. [CrossRef] [PubMed]

126. Aizawa, E.; Tsuji, H.; Asahara, T.; Takahashi, T.; Teraishi, T.; Yoshida, S.; Ota, M.; Koga, N.; Hattori, K.; Kunugi, H. Possible Association of Bifidobacterium and Lactobacillus in the Gut Microbiota of Patients with Major Depressive Disorder. J. Affect. Disord. 2016, 202, 254-257. [CrossRef] [PubMed]

127. Messaoudi, M.; Lalonde, R.; Violle, N.; Javelot, H.; Desor, D.; Nejdi, A.; Bisson, J.-F.; Rougeot, C.; Pichelin, M.; Cazaubiel, M.; et al. Assessment of Psychotropic-like Properties of a Probiotic Formulation (Lactobacillus Helveticus R0052 and Bifidobacterium Longum R0175) in Rats and Human Subjects. Br. J. Nutr. 2011, 105, 755-764. [CrossRef] [PubMed]

128. Benton, D.; Williams, C.; Brown, A. Impact of Consuming a Milk Drink Containing a Probiotic on Mood and Cognition. Eur. J. Clin. Nutr. 2007, 61, 355-361. [CrossRef] [PubMed]

129. Steenbergen, L.; Sellaro, R.; van Hemert, S.; Bosch, J.A.; Colzato, L.S. A Randomized Controlled Trial to Test the Effect of Multispecies Probiotics on Cognitive Reactivity to Sad Mood. Brain Behav. Immun. 2015, 48, 258-264. [CrossRef] [PubMed]

130. Tillisch, K.; Labus, J.; Kilpatrick, L.; Jiang, Z.; Stains, J.; Ebrat, B.; Guyonnet, D.; Legrain-Raspaud, S.; Trotin, B.; Naliboff, B.; et al. Consumption of Fermented Milk Product With Probiotic Modulates Brain Activity. Gastroenterology 2013, 144, 1394-1401.e4. [CrossRef] [PubMed]

131. Marin, I.A.; Goertz, J.E.; Ren, T.; Rich, S.S.; Onengut-Gumuscu, S.; Farber, E.; Wu, M.; Overall, C.C.; Kipnis, J.; Gaultier, A. Microbiota Alteration Is Associated with the Development of Stress-Induced Despair Behavior. Sci. Rep. 2017, 7, 43859. [CrossRef] [PubMed]

132. Gao, J.; Xu, K.; Liu, H.; Liu, G.; Bai, M.; Peng, C.; Li, T.; Yin, Y. Impact of the Gut Microbiota on Intestinal Immunity Mediated by Tryptophan Metabolism. Front. Cell. Infect. Microbiol. 2018, 8, 13. [CrossRef] [PubMed] 
133. Genestet, C.; Le Gouellec, A.; Chaker, H.; Polack, B.; Guery, B.; Toussaint, B.; Stasia, M.J. Scavenging of Reactive Oxygen Species by Tryptophan Metabolites Helps Pseudomonas Aeruginosa Escape Neutrophil Killing. Free Radic. Biol. Med. 2014, 73, 400-410. [CrossRef] [PubMed]

134. Zheng, X.; Xie, G.; Zhao, A.; Zhao, L.; Yao, C.; Chiu, N.H.L.; Zhou, Z.; Bao, Y.; Jia, W.; Nicholson, J.K.; et al. The Footprints of Gut Microbial-Mammalian Co-Metabolism. J. Proteome Res. 2011, 10, 5512-5522. [CrossRef] [PubMed]

135. El Aidy, S.; Merrifield, C.A.; Derrien, M.; van Baarlen, P.; Hooiveld, G.; Levenez, F.; Doré, J.; Dekker, J.; Holmes, E.; Claus, S.P.; et al. The Gut Microbiota Elicits a Profound Metabolic Reorientation in the Mouse Jejunal Mucosa during Conventionalisation. Gut 2013, 62, 1306-1314. [CrossRef] [PubMed]

136. Jaglin, M.; Rhimi, M.; Philippe, C.; Pons, N.; Bruneau, A.; Goustard, B.; Daugé, V.; Maguin, E.; Naudon, L.; Rabot, S. Indole, a Signaling Molecule Produced by the Gut Microbiota, Negatively Impacts Emotional Behaviors in Rats. Front. Neurosci. 2018, 12, 216. [CrossRef] [PubMed]

137. Biagini, G.; Pich, E.M.; Carani, C.; Marrama, P.; Gustafsson, J.-Å.; Fuxe, K.; Agnati, L.F. Indole-Pyruvic Acid, a Tryptophan Ketoanalogue, Antagonizes the Endocrine but Not the Behavioral Effects of Repeated Stress in a Model of Depression. Biol. Psychiatry 1993, 33, 712-719. [CrossRef]

138. Tigchelaar, E.F.; Zhernakova, A.; Dekens, J.A.M.; Hermes, G.; Baranska, A.; Mujagic, Z.; Swertz, M.A.; Muñoz, A.M.; Deelen, P.; Cénit, M.C.; et al. Cohort Profile: LifeLines DEEP, a Prospective, General Population Cohort Study in the Northern Netherlands: Study Design and Baseline Characteristics. BMJ Open 2015, 5, e006772. [CrossRef] [PubMed]

139. Sudlow, C.; Gallacher, J.; Allen, N.; Beral, V.; Burton, P.; Danesh, J.; Downey, P.; Elliott, P.; Green, J.; Landray, M.; et al. UK Biobank: An Open Access Resource for Identifying the Causes of a Wide Range of Complex Diseases of Middle and Old Age. PLoS Med. 2015, 12, e1001779. [CrossRef] [PubMed]

140. Falony, G.; Joossens, M.; Vieira-Silva, S.; Wang, J.; Darzi, Y.; Faust, K.; Kurilshikov, A.; Bonder, M.J.; Valles-Colomer, M.; Vandeputte, D.; et al. Population-Level Analysis of Gut Microbiome Variation. Science 2016, 352, 560-564. [CrossRef] [PubMed] 